Piotr CZAJKOWSKI

\title{
TŁUMACZENIE SEMILEKSEMÓW W LITERATURZE SERBSKIEJ NA JĘZYK POLSKI
}

\section{Semilexes Translation from Serbian Literature into Polish}

Keywords: Serbian literature, semilex, translation theory, cultural context

Contact: Uniwersytet Jana Kochanowskiego w Kielcach; piotrczajkowski@ poczta.onet.pl

Bez literatury trudno wyobrazić sobie język i świat w niej odzwierciedlony. Każdy naród i państwo mają własną literaturę narodową, która jest elementem dziedzictwa historycznego i ludowego. Tłumaczenie literatury pięknej jest najbardziej kreatywnym i niezwykłym rodzajem tłumaczenia, wymagającym od tłumacza niewątpliwie talentu i specyficznych umiejętności językowych o charakterze bilingwalnym. Dzieło literackie ujawnia indywidualny styl artystyczny pisarza. Styl każdego pisarza to także system selekcji i organizacji środków językowych, podporządkowany projektowi ideologicznemu i artystycznemu, związany ze złożoną treścią dzieła. Boy uważa, że przekład jest to rzecz trudna; pod względem formalnym trudniejsza niż pisanie, łatwej bowiem znaleźć formę dla myśli własnej, (...) nie dla myśli cudzej powstałej z zupełnie innego ducha. Wymaga nie tylko znajomości mowy obcej (to rzecz najdrobniejsza), ale ogólnej znajomości literatury i kultury danego kraju; wreszcie przede wszystkim, panowania nad własnym, ojczystym językiem (Boy-Żeleński 1922: 285).

Tłumaczenie literackie jest rodzajem tłumaczenia, które jest uważane za najtrudniejsze. Różni się od prawnego lub medycznego tym, że thumacz musi nie tylko poprawnie przekazać wszystkie konstrukcje morfologiczne i syntaktyczne, ale także zachować pierwotny styl, przekazać czytelnikowi, który nie jest w stanie odczytać dzieła w oryginale, wszystkie pomysły autora i wskazówki zaszyfrowane w tekście i rozpoznane przez tłumacza. Osoba zaangażowana w tłumaczenie literackie musi mieć wyczucie stylu i poruszać się w globalnym kontekście kulturowym. Aby tłumaczenie było poprawne, konieczne jest przekazanie w nim ekwiwalentnych wyrazistych środków użytych w oryginale. Roman Jakobson ,podkreśla, że dokonując przeredagowania, przekładu właściwego bądź transmutacji, z reguły nie osiągamy pełnej ekwiwalencji znaków, przekład bowiem ujawnia zwykle nierównoważność 
poszczególnych elementów kodu, ich pewną asymetrię". Z kolei Jerzy Pieńkos odnotowuje, że, „wszelki przekład jest zawsze ekwiwalencją. Przekład, który nie jest ekwiwalentny, nie jest przekładem. Oryginał i przekład są ekwiwalentne, jeśli dają się wzajemnie wymienić w konkretnej sytuacji” (Pieńkos 2003: 170).

Zasadniczy problem pojawia się $\mathrm{w}$ momencie trafienia $\mathrm{w}$ tekście na tzw. semileksemy czyli wyrazy ułomne, mające znaczenie bardzo ogólne i charakteryzujące się defektami fleksyjnymi (SPLP 2016: 9). Problemy ich tłumaczenia mogą mieć związek z niedookreślonością, która znacznie wpływa na proces odbiorczy. Są wykładnikami emocji a także nośnikami emotywnych komunikatów, niejednokrotnie pełne sprzeczności, nieprzewidywalne, stanowią niewątpliwie wyzwanie dla badaczy. Tak dzieje się z ich translacją np. w powieści jugosłowiańskiego noblisty Ivo Andricia pt. Na Drini Ćuprija (Most na Drinie). Jest to książka niezwykła nie tylko ze względu na opisaną historię, ale również niepowtarzalny styl autora, który charakteryzuje się zapożyczeniami z języka tureckiego i perskiego. Tłumaczenia tego dzieła podjęła się polska tłumaczka Halina Kalita. W odtworzeniu narodowych cech oryginału, Kalita musiała pokonać barierę językowo-etniczną, aby przekazać nie tylko zrozumiałą treść semantyczną, opisywanej rzeczywistości, ale także stylistyczną i wyrazistą emocjonalną kolorystykę wypowiedzi bohaterów. Takie procesy wymagają rozwiązania różnych kwestii, m.in. określenia ideologicznych $\mathrm{i}$ artystycznych intencji autora, oraz zrozumienia specyfiki samych semileksemów, które w większości serbskich i serbskochorwackich gramatyk, występują najczęściej w funkcji wykrzykników, onomatopei czy partykuł. W dialogach bohaterów Andricia realizowana jest cała gama środków językowych, wyrażonych przez dialekty, gwary czy zapożyczenia. Dla tłumacza to prawdziwe wyzwanie. Musi on wybrać nie tylko proste odpowiedniki, ale także równoważne emocjonalnie wyraziste wartości odzwierciedlone w kompozycji języka źródłowego. Tłumacząc tekst literacki można wybrać jeden $\mathrm{z}$ dwóch sposobów. Pierwszy jest formalnym przeniesieniem zewnętrznej strony tekstu na inny język (słownictwo, struktura zdań). Drugi sposób jest bardziej kreatywny. Tłumacz w tym przypadku staje się współautorem dzieła, starając się przekazać nie tyle szkielet, co nowego ducha twórczego. Oba sposoby są równie interesujące, ale równie niebezpieczne - zawsze istnieje ryzyko, że można przeoczyć coś ważnego.

Idealne tłumaczenie literackie powinno odzwierciedlać subtelności treści oryginalnego tekstu, jego system graficzny. Powinno być wykonywane z uwzględnieniem cech semantycznych i ekspresywnych oraz możliwości zarówno języka źródłowego, jak i docelowego. U Haliny Kality widać wyraźnie rozbieżność w thumaczonych przez nią semileksemach użytych przez Andricia. Tak dzieje się choćby w przypadku leskemu ajde! Jego słownikowa definicja brzmi: chodź! pójdź! 
nuże! (SPS 1999: 5) i oznacza: podniecenie czymś: dela, dede, groźba, rozkaz, pozwolenie czy ustępstwo. U Andricia ajde pojawia się często np. w zdaniu zaczerpniętym z dialogu dwóch sąsiadów w dodatku dobrych przyjaciół:

- Ајде, јадан, док је Дрина Дрина и ћуприја би била ћуп-рија; и да је дарнули

нису, трајала би колико јој је писано (Andrić 1956: 230).

Ich rozmowa skupia się wokół restaurowanego mostu. Jednemu z nich wcale nie podoba się pomysł renowacji budowli. I mówi:

- No, no przyjacielu, jak Drina Drina most byt mostem; nawet gdyby go nie tknęli,

stałby póty póki mu pisane (Kalita 1956: 261).

Znaczenie tego semileksemu nabiera $w$ tym kontekście zupełnie inne nacechowanie. Ajde tym przypadku przybiera formę dezaprobaty. Pojawia się przez to wiele nieścisłości. Według tłumaczki ajde jest leksemem równoważnym partykule no w reduplikacji. W zacytowanym wyżej zdaniu niestety w żaden sposób nie wyczuwa się tonu dezaprobaty przypisanej temu leksemowi. Co więcej tryb przypuszczający użyty w stwierdzeniu most byłby mostem został zastąpiony przez Halinę Kalitę użyciem czasu przeszłego most był mostem. Dodatkowo oryginalny rzeczownik jadau (nieszczęśnik) w przekładzie został zastąpiony przyjacielem. Tak więc, w znalezieniu ekwiwalentu o najwyższym poziomie zgodności wraz z jego ekspresyjnymi i estetycznymi właściwościami ogromną rolę odgrywa znajomość kultury językowej zawartej w tekście źródłowym. Tłumaczenie literackie zostanie uznane za naprawdę odpowiednie tylko wtedy, gdy w pełni odda intencję autora, formę, styl dzieła literackiego z jego najsubtelniejszymi niuansami semantycznymi i całą mocą wpływu emocjonalnego na czytelnika.

Istnieje bardzo subtelny problem w międzykulturowej adaptacji tłumaczonego tekstu. Chodzi głównie o rozbieżność między poziomem normy emocjonalnej w różnych kulturach i językach. Ta różnica sprawia, że styl stanowi prawdziwą barierę w komunikacji. Tłumaczenie dzieł Andricia nie należy więc do łatwych. Warto przywołać jeszcze jedną scenę z Mostu na Drinie. W kasabie mieszkał Włoch, Pietro Sola, z zawodu murarz i kamieniarz. Był to człowiek o dobrego serca o przyjaznym usposobieniu a przy okazji świetny fachowiec. Wszystko zmieniło się kiedy w Genewie doszło do zabójstwa cesarzowej Elżbiety, a zamachowcem okazał się włoski anarchista Laccheni. Kiedy wieść o tym tragicznym wydarzeniu dobiegła także do kasaby, reakcja 
mieszkańców była natychmiastowa. Mistrz Pero jak zdrobniale nazywali go sąsiedzi dostał od dzieci niechlubny przydomek włoskiego zbrodniarza. Pełen przygnębienia i wstydu wyznał żonie w jednej z rozmów:

- Стид ме, стид ме - јецао је ситни човек - у оци ником не могу да погледам.

- Ајде, будалашу, чега те стид? Што је Талијан убио ичарицу? Нек се стиди

талијански краљ! А ко си ти и шта си да се ти стидиш?

$\mathrm{W}$ tej scenie ajde w połączeniu $\mathrm{z}$ wyrazem будаламy (głuptasku) $\mathrm{w}$ odniesieniu do ukochanego męża ma charakter deminutywny, nacechowany pozytywnymi emocjami. Stana, żona Pera mówiąc do niego ajde zaprasza go do siebie i zadaje pytanie чега те стид? Jest pełna troski o Pera. Natomiast w polskim przekładzie czytamy:

- Dajże spokój gluptasie, czego się masz wstydzić?

Nie ma tego ciepła w tłumaczeniu Haliny Kality. Brak jest troski i łagodności. W głosie Steny odczuwa się raczej obojętność i ignorancję.

$\mathrm{Na}$ podstawie analizowanych wypowiedzi widać unikatowe formy językowe, odzwierciedlające konotacje kulturowe, często nacechowane emocjonalnie. Tak więc obraz tekstu literackiego jest jednym z ważnych obszarów badań nad przekładem. Równie ważne są metody przekazywania w tłumaczeniu specyficznych dla kraju cech językowego obrazu świata $z$ oryginalnego tekstu na język innej kultury językowej. Należy przy tym pamiętać o właściwym wyborze strategii i technologii thumaczeniowych tak by zostało utrzymanie adekwatności poprzez zastosowanie niezbędnych przekształceń translacyjnych oraz zachowanie emocjonalnej i estetycznej funkcji tekstu źródłowego.

Bywają czasami sytuacje w których autor przekładu staje przed koniecznością opatrzenia nieprzekładalnego $\mathrm{z}$ powodów kulturowych fragmentu, krótkim wyjaśnieniem lub komentarzem. Tak też jest $\mathrm{w}$ przypadku zaczerpniętego $\mathrm{z}$ języka tureckiego zwrotu аја јок! Semileksem ten został opatrzony przypisem jako zwrot ależ nie!

W tłumaczeniu na język docelowy ważne jest zachowanie nie tylko pragmatycznego potencjału oryginału, jego komunikatywnego efektu, ale także artystycznych ujęć oryginalnego tekstu. Dlatego podczas międzykulturowej adaptacji przetłumaczonego tekstu należy zwrócić bardziej szczególną uwagę nie tylko na 
merytoryczne, semantyczne i ideologiczne aspekty, ale na zachowanie emocjonalność i ekspresyjność w tekście źródłowym przy zachowaniu jego walorów estetycznych i kulturowych.

Literatura serbska charakteryzuje się bogactwem semileksemów. Tak dzieje się choćby w powieści Miodraga Bulatovicia pt. Bohater na ośle przetłumaczonej na język polski przez Danutę Cirlić-Straszyńską. W jednym z jej fragmentów pojawia się takie oto zdanie:

- Grkinja! - kliknu major i prsnu u zarazan smeh. - Tvoja slatka, tvoja jedina, tvoja nezamenljiva i egzotična Aliki. Hi, hi, hi ... (Bulatowić 1994: 10).

Użyty w oryginale semileksem $h i \mathrm{w}$ reduplikacji jest ekwiwalentny do tłumaczenia zaproponowanego przez tłumaczkę a mianowicie:

- Greczynka! - zawołał major i wybuchną zaraźliwym śmiechem Twoje cudo, twoja jedyna, twoja niezastapiona i egzotyczna Aliki. Hi, hi, hi ... (Cirlić 1977: 30).

Podobny zabieg tłumaczka stosuje przy translacji innego zdania. Chodzi o sytuację w której Włoch Augusto zaskakuje żołnierza i budzi go ze snu. Ten zdezorientowany odruchowo chwyta za karabin i mówi:

- Oh, Augusto. To si ti, đavole ... (Bulatović 1994: 15).

Och jest semileksemem o wielu znaczeniach. Jest to najczęściej westchnienie za którego pomocą można wyrazić zarówno pozytywne jak i negatywne emocje. W zależności od intencji może to być zachwyt, żal, smutek a nawet ból. CirlićStraszyńska używa tego samego semileksemu, który ma identyczne znaczenie w języku polskim i serbskim. Różni się jedynie zapisem fonetycznym. Zdanie to brzmi:

- Och Neapolitano. To ty szatanie. (Cirlić 1977: 36).

W tym kontekście znaczenie och ma ekwiwalentny i oznacza zdziwienie.

$\mathrm{Na}$ uwagę zasługuje zdanie w którym semileksem $\mathrm{hm}$ został użyty przez tłumaczkę, podczas gdy w oryginalnym, tekście w ogóle nie występuje. Tak dzieje się gdy pułkownik prosi kaprala o radę i nie dostaje od niego jasnej odpowiedzi. Zdanie to brzmi: 
- Hm..., gdybym byt na Pana miejscu - zająknął się Turiddu - gdybym byt na Pana miejscu... - Przestań się jąkać porca miseria!

W oryginale czytamy:

- Dakle, da sam na vašem mestu - zamuca Turiddu: - Da sam na vašem mestu ...

- Ne zamuckuj, porca miseria! (Bulatović 1994: 39).

W tym kontekście widać zaangażowanie tłumaczki w ukazanie stanu emocji w tym przypadku zakłopotania, wręcz strachu przed odpowiedzią na pytanie pułkownika. Podobnie jest w zdaniu: - Boży człowiek, uch! (Cirlić 1977: 107), w którym również został użyty leksem $u c h$, nie istniejący w tekście Bulatovicia.

W zakresie adekwatności tłumaczenia literatury ważne są systematyczne badania, identyfikujące cechy analizy porównawczej tłumaczeń, chęć zrozumienia problemu odpowiedniego przekazania języka i stylu autora tekstu literackiego. Porównawcze badania języków w zakresie gramatyki, słownictwa, stylistyki, pragmatyki na podstawie tłumaczeń fikcyjnych umożliwiły identyfikację leksykalną, semantyczną. morfologiczną i składniową.

W odróżnieniu od techniki przedstawionych przez tłumaczy z ubiegłego wieku dzisiejsze poglądy na temat tłumaczeń przesuwają się w kierunku problemów ludzkich, zmieniając ich znaczenie $\mathrm{w}$ porównaniu $\mathrm{z}$ tradycyjną definicją przekładu. Uwaga lingwistów na dwujęzyczność, hermeneutykę i porównawcze aspekty typologiczne jest obecnie zdeterminowana przez rosnące znaczenie dostosowania niektórych pojęć, które dziś znajdują odzwierciedlenie we współczesnym językoznawstwie. Wzorce te stanowią podstawę badań naukowych nad tłumaczeniami dotyczącymi ekwiwalentów w systemie metajęzykowym, prognozowania przekształceń w thumaczeniu, kategorii, wzorców tłumaczenia między tekstami źródłowymi i językami tłumaczenia, strategii komunikacyjnej, technologii i metod tłumaczenia. tłumaczenie dzieł poetyckich i literackich, które znacznie różnią się od innych rodzajów tłumaczenia i wymagają nie tylko użycia starego, zapamiętanego raz na zawsze, ale wymagają kreatywności słownej. Takie thumaczenie jest prawdziwą sztuką, ponieważ efekt estetyczny osiąga się za pomocą odpowiednich środków językowych, w tym rytmu, rymu i aliteracji. Tłumacz musi zachować niezmienioną treść oryginalnego tekstu, co oznacza, że nie jest uprawniony do wdrożenia żadnego ze swoich narzędzi. Tłumaczenie dzieł literackich nie jest rzeczą łatwą. 
Tłumacząc dzieła literackie, tłumacz powinien zapoznać się z innymi dziełami autora. Zadaniem tłumacza literatury jest zrozumienie tego, co autor chciał powiedzieć, a następnie jasne określenie idei zawartych w języku oryginału.

\section{Summary}

The problems of literary translation, along with questions about the general theory of translation, as well as special types of translation, are contained in the general philosophical paradigm of knowledge in which translation is considered as an interdisciplinary phenomenon. As a subject of research in the aspect of translation, a very broad range of topics are particularly interesting: problems of language and culture; language and thinking; style and genre; primary and secondary text; translator's linguistic personality; translation of terms; translations; differentiating a language mark in two texts belonging to different languages; translation units and strategies for effective translation of literary texts, including media ones; preservation of countryspecific features of the original work and means of expression in translate; cognitive mechanisms of embodiment using the language of artistic image.

\section{Literatura}

Andrić, I. Most na Drinie. Tłum. Kalita, H. Warszawa: Czytelnik, 1956.

Andrić, I. Na Drini Ćuprija. Knj. 30. Beograd: NOLIT, 1981.

Boy-Żeleński, T. Nowe studia z literatury francuskiej. Kraków: KSW, 1922.

Bukowski, P., Heydel, M. Przekład-język-literatura. In: Bukowski, P., Heydel, M. (eds.) Współczesne teorie przekładu Antologia. Kraków, 2009.

Bulatović, M. Heroj na magarcu. Beograd: Prosveta, 1994.

Bulatović, M. Bohater na ośle. Tłum. Cirlić-Straszyńska, D. Łódź: Biblioteka jugosłowiańska, 1977.

Krzysztofiak, M. Przekład literacki a translatologia. Poznań: Wydawnictwo Naukowe UAM, 1999.

Pieńkos, J. Podstawy przekładoznawstwa. Od teorii do praktyki. Kraków: ZAKAMYCZE, 2003.

SPLP - Słownik polskich leksemów potocznych. Tom 9. Lubaś, W. (ed.) Kraków: Wydawnictwo Lexis, 2016. 
SPS - Stownik polsko-serbski. Tom 1. Živanović, Đ. (ed.) Beograd: Serbska Akademia Nauk, 1999. (c) $\left(\begin{array}{l}\text { (1) } \\ \text { BY NC ND }\end{array}\right.$ The article is accessible in open access mode under licence CC BY-NC-ND 